\title{
INDEX OF AUTHORS
}

Adron, J. W.

Ankers, C.

Atherton, S. J.

Ball, F. M.

Balnave, D.

Bibby, R. J.

Breckenridge, G.

Buss, D. H.

Buttery, P. J.

Bruce, J. B.

Cadenhead, A.

Carver, M. E.

Chan, A. C.

Cowey, C. B.

Crofts, R. M. J.

Cumming, R. B.

Czerkarwski, J. W.

Dako, D. Y.

Davies, D.

Davies, N. T.

$\begin{array}{lr}\text { Davies, N. T. } & 407,417 \\ \text { DeLa Higuera Gonzales, M. } & 385\end{array}$

Ford, J. F.

Fuller, M. F.
385,463

319,329

341

371

507

455

489

489

497

361

385,463

479

319,329

371

353

341

507

479,489
Gous, R. M.

Grovum, W. L.

Grubb, D. A.

Hamilton, W. J.

Hegarty, P. V. J.

Hill, R.

Hyvärinen, $\mathrm{H}$.

Kay, R. N. B.

Knox, D.

Leng, R. A.

Lennon, D.

Leonard, M. C.

Lewis, D.

McDonald, I.

McDonald, J. D.

Mallick, N. P.

Mehrez, A. Z.

Milner, J.

Ørskov, E. R.

Pimstone, B.
313 Ranjhan, S. K.

425 Ricketts, C. R.

Schorah, C. J.

Scott, K. J.

Shapiro, B.

Singh, A. B.

Smith, I. M.

301, 397

Smithells, R. W.

Sutherland, T. M.

Toutain, C.

Toutain, P. L.

Varma, A.

Walton, M. J.

Watson, J. D.

Williams, R. B.

\section{FORTHCOMING PAPERS}

The next issue of the British Journal of Nutrition will appear in January 1978. It is hoped to publish in it the following papers. Papers of direct relevance to CLINICAL AND HUMAN NUTRITION

Availability of calcium from a leafy vegetable rich in oxalates. By URMILA PINGLE and B. V. RAMASASTRI

Leucocyte ascorbic acid and pregnancy. By C. J. SCHORAH, P. M. ZEMroch, S. SHEPPARD and R. M. SMTrHELlS

Serum cholesterol, triglycerides and heart disease of nomadic and sedentary tribesmen consuming isoenergetic diets of high and low fat content. By M. J. Murray, Anne B. Murray, N. J. Murray and Megan B. Murray

Deposition of fat in the body of the rat during rehabilitation after early undernutrition. By PATRICIA M. HARRIS and ELSIE M. WIDDOWSON

Papers on GENERAL NUTRITION

Fertilizer sulphur as a factor affecting voluntary intake digestibility and retention time of Digitaria decumbens (pangola grass) by sheep. By M. C. REES and D. J. MrNSON

Protein utilization in rats receiving a low-protein diet with various limiting amino acids. By H. RAFALSKI, E. JABLONSKI and TERESA SwITONIAK

The effect of different dietary fats on fat cell size, number and chemical composition in rat epididymal fat pad. By JANET KIRTLAND and M. I. GURR

Overfeeding influence on growth, obesity and intestinal tract in young chicks of light and heavy breeds. By I. NIR, Y. DRoR,

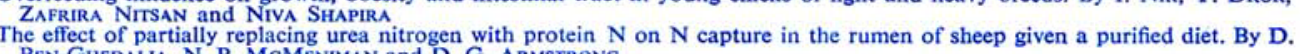
Ben-Ghedalia, N. P. MCMENiman and D. G. Armstrong

Fatty acid composition of tissue phospholipids of the foetal calf and neonatal lamb, piglet and deer calf as compared with the cow, sheep, deer and pig. By E. PAYNE

The polyunsaturated fatty acid status of foetal and neonatal ruminants. By E. PAYNE

Effect of leucine at different levels of vitamin $\mathrm{B}_{6}$ on hepatic quinolinate phosphoribosyl transferase and leucine aminotransferase in experimental animals. By KAMALA KRISHNASWAMY and S. BAPURAO

Quantitative aspects of the transformations of sulphur in sheep. By P. M. KENNEDY and L. P. MILLIGAN

Effect of refeeding raw and cooked starches on hepatic enzyme activities of rats. By OtHo E. Michaelis IV, CharLOTTE S. NACE

The influence of the gut microflora and of dietary fibre on epithelial cell migration in the chick intestine. By B. A. ROLLS, A. TURVEY and MARIE E. COATES

Nitrogen excretion in germ-free and conventional chickens: effects of an alkali load. By J. OKUMURA, D. HEwrrT and MARIE E. COATES

Effects of cold exposure on digestion, microbial synthesis and nitrogen transformations in sheep. By P. M. KENNEDY and L. P. MILLIGAN

The vitamins of the B group and the activity of hepatic microsomal mixed-function oxidases of the Wistar rat. By R. MnteNBERGER and U. OLTERSDORF

Response of lipogenic enzymes to overfeeding in liver and adipose tissue of light and heavy breeds of chicks. By Niva SHAPIRA, I. NIR and A. BUDOWSKI

The simultaneous use of ribonucleic acid, ${ }^{3} \mathrm{~S}, 2$,6-diaminopimelic acid and 2-aminoethylphosphonic acid as markers of microbial nitrogen entering the duodenum of sheep. By J. R. LING and P. J. BUTTERY

The effects of dietary nitrogen level on the collagen of rat skin. By R. DAwSON and G. MILNE

Efficiency of use of nitrogen from dried microbial cells following nitrogen deprivation in growing pigs. By C. T. WHrrremore, J. BRONWYN TULLIS and SANDRA W. HASTIE

The effect of dietary calcium intake of ewes in pregnancy on their calcium and phosphorus metabolism in lactation. By G. D. BRAITHWAITB

The effects of feeding and acute cold exposure on the visceral release of volatile fatty acids, estimated hepatic uptake of propionate and release of glucose, and plasma insulin concentration in sheep. By G. E. ThompSON, J. M. BASSETT and A. W. BELL. 


\title{
The British Journal of Nutrition
}

\author{
Volume 38 No. 3 November 1977
}

\section{CONTENTS}

Papers of direct relevance to CLINICAL AND HUMAN NUTRITION

Intravenous infusion of a dextrin, Caloreen, in human subjects: metabolic studies. By R. J. Bibby, D. Davies, N. P. Mallick, S. J. Atherton, D. M. Wright, C. R. Ricketts and

J. MrLNER
Anthropometric studies on African athletes who participated in the ist African University Games. By J. D. WATSON and D. Y. DAKO

Maternal nutrition in early pregnancy. By R. W. Smithells, Carol Ankers, Margaret E. CARVer, Dorothy LenNon, C. J. Schorah and Sheila Sheppard . : .

The histology and in vivo sulphate uptake of epiphyseal cartilage in protein-depleted rats. By B. SHAPIRO and B. PIMSTONE

Variation in the weight, specific gravity and composition of the antlers of red deer (Cervus

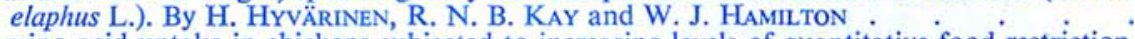

Amino acid uptake in chickens subjected to increasing levels of quantitative food restriction. By R. M. Gous .

A biochemical explanation for the fatty liver and kidney syndrome of broilers: its alleviation by the short-term use of dietary fat. By D. BALnAve, R. M. Cumming and T. M. SUTHERLAND

Studies of fatty liver and kidney syndrome in chickens: dynamics of glucose metabolism. By D. Balnave, J. Wolfenden, F. M. Ball, R. B. Cumming and R. A. Leng

The relationship between rumen bacterial growth, intake of dry matter, digestible organic matter and volatile fatty acid production in buffalo (Bos bubalis) calves. By A. B. SINGH,

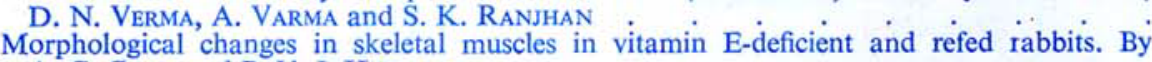

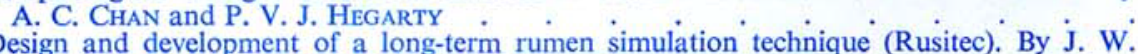
CZERKAWSKI and GRACE BRECKENRIDGE

The effect of dietary composition and of insulin on gluconeogenesis in rainbow trout $(\dot{S} a l m o$ gairdneri $)$. By C. B. Cowey, M. DE LA Higuera Gonzales and J. W. Adron .

Effect of postruminal glucose or protein supplementation on milk yield and composition in Friesian cows in early lactation and negative energy balance. By E. R. ØRSKOV, D. A. GRUBB and R. N. B. KAY

The effects of pregnancy and lactation on copper and zinc retention in the rat. By $\dot{R}$. $\dot{B}$. Williams, N. T. Davies and I. MCDonald

The effect of pregnancy and lactation on the adsorption of zinc and lysine by the rat duodenum in situ. By N. T. DAvies and R. B. WILliams .

Rate of passage of digesta in sheep. 6. The effect of level of food intake on mathematical predictions of the kinetics of digesta in the reticulorumen and intestines. By W. L. GROVUM and V. J. WILLIAMS

Rates of rumen fermentation in relation to ammonia concentration. By A. Z. MEHREZ, E. R. ØrSKOV and I. MCDONALD . . . . . . . . . . . . . . . . . .

Sleep and activity, age and fatness, and the energy expenditure of confined sheep. By P. L. Toutain, Claire Toutain, A. J. F. Webster and J. D. McDonald .

The effects on glucose metabolism of feeding a high-urea diet to sheep. By M. C. LEONARD, P. J. BuTterY and D. LEWIS
The regulation of gluconeogenesis by diet and insulin in rainbow trout (Salmo gairdneri). By C. B. Cowey, D. Knox, M. J. Walton and J. W. Adron

The influence of protein source and basal dietary component on survival in acute experimental fowl typhoid in the chick (Gallus domesticus). By R. HILL and I. M. SMITH

The protein-sparing effect of carbohydrate. 1 . Nitrogen retention of growing pigs in relation to diet. By M. F. Fuller and R. M. J. Crofts

The protein-sparing effect of carbohydrate. 2. The role of insulin. By M. F. Fulder, T. F. C. WeEkes, A. CADENHEAD and J. B. BRUCE . . . . . . . . .

The B-vitamin content of baboon (Papio cynocephalus) milk. By D. H. Buss, J. F. Ford and K. J. ScoTT. 